\title{
Az információs társadalom mint az oktatás tárgya
}

Mára már elfogadottnak tekinthető az információs társadalomra vonatkozó tudomány (information society studies) léte, de még nyitott kérdés az, hogy ennek a stúdiumnak - ami rohamos tempóban válik tantárggyá és terjed a világ egyetemein - mi a tárgya, milyen a belső szerkezete, és hogyan közelíthető meg a tantárgypedagógia hagyományos módszereivel.

Z. Karvalics László tanulmányában az erre irányuló rendszerezési elképzeléseket gyüjtötte össze, s tekinti át, külön kiemelve azokat a sajátosságokat, amelyek életkori vagy „müfaji” szempontból igényelnek egyedi megoldásokat - kitérve a hazai helyzetre is.

\section{Szerzői információ:}

\section{Z.Karvalics László}

Történész-informatikus, a Budapesti Mûszaki-és Gazdaságtudományi Egyetem Információmenedzsment Tanszékének docense, az 1998-ban alapított ITTK (Információs Társadalom-és Trendkutató Központ) igazgatója és az 1992 óta létező Információtörténelem Múhelykurzus vezetôje. Számos, információs társadalommal foglalkozó kurzus kidolgozója, szakkönyv és tanulmány szerzôje. Nagy siker volt 2000-ben megjelent könyve, az Internettel foglalkozó "Fogpiszkáló a hálózaton,", és sokan forgatják 2002-es, „Az információs társadalom keresése” címú tanulmánykötetét is. Kar Kiváló Oktatója (1999), Széchenyi-Ösztöndíjas (2000-tốl). Folyóiratunk fôszerkesztôje. 
Z. Ka rvalics Lás z ló

\section{Az információs társadalom mint az oktatás tárgya}

2001 májusában egynapos tanácskozást tartottak a Napier Egyetemen, Edinburghben, ahol a résztvevők arra a kérdésre kerestek választ, hogy miképpen lehet azonosítani és hogyan lehet tanítani a felsôoktatásban azt a tárgyat, amit röviden „információs társadalomnak” nevezünk.

Ez az egyszerú hír közvetett módon azt is jelzi, hogy mostanra már nem az a kérdés, beszélhetünk-e egyáltalán az információs társadalomra vonatkozó tanulmányok ${ }^{1}$ (information society studies) létjogosultságáról, hanem sokkal inkább az, hogy ennek a stúdiumnak - ami rohamos tempóban válik tantárggyá és terjed a világ egyetemein - mi a tárgya, milyen a belsố szerkezete, és hogyan közelíthetố meg a tantárgypedagógia hagyományos módszereivel. Mindenekelő́tt tehát az erre irányuló rendszerezési elképzeléseket kell áttekintenünk.

\section{A tárgy tartalma: mit oktassunk aะ információs társadalommal kapcsolatos ismeretkörböl?}

Alistair S. Duff az alábbi négy fontos jellemző vonást emeli ki:

- ennek a területnek - a meglévő tartalmi konszenzusok ellenére - még nincs egységes, kodifikált „értelmezési tartománya”;

- számos sui generis iskola egyidejú jelenléte jellemzi;

- a társadalomtudományi spektrumban makroszinten helyezkedik el;

- a mezo- és mikroszintre a „társadalmi informatika” (social informatics) kifejezés tûnik alkalmasnak².

\footnotetext{
'A kérdést évekkel ezelốtt megnyugtatóan tisztázta Alistair S. Duff könyve (Duff 2000). Nem igyekszünk tehát igazolni, hogy ez a diszciplína létezik, egyszerúen adottként és elfogadottként beszélünk róla. Duff elôadása az edinburghi konferencián (Duff 2001b) számos friss érvvel járta körül a kérdést, utalva fontos attribútumok (szakmai folyóiratok, konferenciák) további „felfejlődésére” és a Keresztesi-féle tudománytipológiának való megfelelés kérdéseire is. Ezért szükségtelennek tartjuk, hogy hosszadalmasan és körülményesen közelítsük meg az információs társadalom problémakörét. In medias res, annak oktatásával foglalkozunk.

${ }^{2}$ Duff-fal egyetértve emlékeztetünk rá, hogy az ily módon szúkített értelemben vett társadalmi informatika a közelmúltban elhunyt Rob Klingnek és az Indiana Egyetemen múködố csoportjának a tevékenysége nyomán vált „bevetté”. Magyarországon 1991 óta oktat társadalmi informatikát a BME-n az az egyetemi múhely, amely sokáig még a nevében is ennek a diszciplínának a megnevezését viselte (most: Információés Tudásmenedzsment Tanszék, ld. Danyi-Gelléri-Z.Karvalics 1993; Z.Karvalics 1998)
} 
Mindebbôl az következik, hogy a tárgy tartalmának kulcskomponense a magáról az információs társadalomról folyó vita. Duff (Duff 2001a) megnevezi azt a három „ôsforrást”, „nyersváltozatot”, amelyekből a rivális múhelyek kinőnek²

- Machlup, Porat és az információgazdaság, tudástermelés paradigmája (az amerikai iskola);

- az ICT diffúziója (ahol a Nora-Minc jelentéssel indul a diskurzus, és Ian Miles tekinthetố a jellegadó alaknak (az európai iskola);

- az úgynevezett „információrobbanás” (a japán iskola).

A továbblépéshez - az egymással feleselő megközelítésektől függetlenül - elsősorban azt kell tisztázni, hogy mik legyenek az információs társadalommal kapcsolatos ismeretkör tantárgyi modullá alakítható pillérei és részterületei.

Black (Black 2001) három vetélkedô, ám egymásra mégiscsak hasonlító modellt vizsgál meg: a társadalom és a technológia találkozásának hagyományos STEP modelljét, ${ }^{4}$ a Webster alapmúvében adott felosztást és Dutton tipológiáját.

1. táblázat

A tantárggyá formálódó tudásterület lehetséges alapmoduljai

\begin{tabular}{l|l|l} 
STEP modell & Webster (1995) & Dutton (1996) \\
\hline Gazdaság & Gazdaság & Termelés (Production) \\
\hline Társadalom & Foglalkoztatottság & Fogyasztás (Consumption) \\
\hline Technológia & Technológia & Felhasználás (Utilization) \\
\hline Politika & & Kormányzás (Governance) \\
\hline (Környezet) & Tér & \\
\hline Kultúra & & \\
\hline
\end{tabular}

\section{Hol és kinek tanitsuk az információs társadalomra vonatkozó ismereteket?}

„Az információs társadalom elméletét és gyakorlatát a középiskolákban, a felsőoktatásban és a felnőttoktatásban is tanítani kell." (Varga 2002)

Ha a fenti elôzetes megfontolásokon túl vagyunk, feltehetjük a következô kérdést: kiknek és milyen formában van szükségük arra, hogy szervezett oktatás keretei között képzést kapjanak az információs társadalomról?

\footnotetext{
Duff felosztását leegyszerûsítônek, hibásnak és végiggondolatlannak tartjuk, de bemutatásától nem zárkóztunk el. Az információs társadalom problémavilága sokkal összetettebb és tagoltabb elméleti térben írható le, erre nézve 1d. Z. Karvalics, 2001. Vitatható Duffnak az a véleménye is, miszerint a terület „vezértudománya” a szociológia és a (könyvtárosi értelemben vett) információtudomány volna. Abban viszont messzemenően egyetértek vele, hogy erős szintézis-igény jellemzi a területet, de ezt nem Daniel Bell, és nem Manuel Castells testesíti meg.

${ }^{4}$ A science, technology, education és policy szavak kezdőbetúibôl álló mozaikszó, ami STEEP-re módosul, ha az environment is beletartozik.
} 
A külföldi és hazai megközelítések nem kellőképpen differenciáltak ebben a kérdésben. A „felsôoktatás” általában homogén felületként jelenik meg, pedig sokszorosan tagolt. Hornby (Hornby 2001) a manchesteri Metropolitan Egyetemen szerzett tapasztalatai alapján leszögezi, hogy az információs társadalomra vonatkozó ismeretek különböző szinteken oktathatók, illetve oktatandók, de egyúttal felhívja a figyelmet arra is, hogy a bevezetô évfolyamokon problematikus lehet a teoretikus összefüggések megértése, a posztgraduális képzésben résztvevő hallgatók ugyanakkor nem kellóen motiváltak az elmélyedésre az egyes jelenségek értelmezésében.

Véleményem szerint az igazi törésvonal máshol húzódik. Egészen másképpen kell ugyanis foglalkozni azokkal a hallgatókkal, akik a társadalomelmélet (szociológia, filozófia, történettudomány) művelőiként elmélyült és áttekintő vizsgálódásokhoz kapnak segítséget a tanórákon, mint mindenki mással, akik számára az értelmiségi léthez hozzátartozó mûveltség gyarapítása végett, „korunk jellegét” megérteni segítő kurzusokon kerítünk sort az információs társadalom ismeretkörének oktatására. ${ }^{5}$ Míg a pedagógusok és az informatikusok számára is egészen speciális céllal (és emiatt más, gazdagabb tartalommal) szükséges képzést szervezni, egészen egyértelmûnek látszik, hogy „az alapok lerakását” már korábban, akár 12-13 éves gyerekekkel el lehet és el is kell kezdeni - az általános iskola utolsó éveiben és a középiskolában azonban nem tantárgyi keretben, hanem irányított beszélgetések formájában. Ezekhez az osztályfőnöki óráktól a meghívott előadókkal való tematikus találkozásokon át a klubrendezvényekig számos fórum kínál megfelelő alkalmakat.

\footnotetext{
${ }^{5}$ Vagyis a tanár szempontjából nézve egyfajta „evangelizációs” praxis részeként is. Ahogy Warner (2001) írja: „az akadémiai világ emberei a prédikátorok analógiájára” cselekszenek. Ugyanez igaz a felnőttoktatásra és a továbbképzésre is: az információs társadalomról szóló oktatás közvetett tudást ad, amelynek szemléletet, kitekintôképességet, valamint megváltozó elemző és transzformációs erőt köszönhetnek mindazok, akik az élethosszig tartó tanulást választják. Earl (2001) már egyenesen a felnôttképzésre szakosított módszertant (,andragogy” of information society studies) kéri számon.
} 


\section{2. táblázat}

\section{Az információs társadalom ismeretkörének nyolc „mikrovilága” az oktatásban}

\begin{tabular}{|c|c|c|}
\hline Kor- és szakmacsoport & $\begin{array}{l}\text { Az ismeretátadás tartalma, } \\
\text { értelme }\end{array}$ & $\begin{array}{l}\text { Jellegzetes oktatási „múfaj” és } \\
\text { segédeszköz-igény }\end{array}$ \\
\hline $\begin{array}{l}\text { Az általános iskola felsô (7-8.) } \\
\text { osztályai }\end{array}$ & $\begin{array}{l}\text { Fogalmi percepció közvetett } \\
\text { módszerekkel }\end{array}$ & $\begin{array}{l}\text { Plakátok, kiadványok, } \\
\text { osztályfốnöki óra }\end{array}$ \\
\hline Középiskola & $\begin{array}{l}\text { Diskurzusok megjelenítése, } \\
\text { beszélgetés, probléma- } \\
\text { „mapping" }\end{array}$ & $\begin{array}{l}\text { Osztályfônöki óra, } \\
\text { Sulinetes cél-oldal }\end{array}$ \\
\hline „Nem szakos" felsőoktatás & $\begin{array}{l}\text { Általános ismeretterjesztés, } \\
\text { szemléletformálás, „awareness } \\
\text { raising” }\end{array}$ & $\begin{array}{l}\text { Szabadon vagy kötelezôen } \\
\text { választható, érdekfeszítô előadás } \\
\text { vagy szeminárium }\end{array}$ \\
\hline $\begin{array}{l}\text { „Szakos” felsőoktatás, } \\
\text { speciális és poszt-graduális } \\
\text { kurzusok }\end{array}$ & $\begin{array}{l}\text { Elmélyült és áttekintố vizs- } \\
\text { gálódások a tudományág alap- } \\
\text { kérdéseiben }\end{array}$ & $\begin{array}{l}\text { Szakszeminárium, magas kredit- } \\
\text { értékű, akár több féléves kurzus }\end{array}$ \\
\hline Szakmai képzés & $\begin{array}{l}\text { Adott foglalkozáshoz szükséges } \\
\text { alapismeretek szisztematikus } \\
\text { átadása (pl. teleház-gazdák }{ }^{6} \\
\text { számára) }\end{array}$ & $\begin{array}{l}\text { Akkreditált szakirány, szak, } \\
\text { komplett képzési csomag, } \\
\text { tantárgycsoportokkal }\end{array}$ \\
\hline Pedagógusképzés & $\begin{array}{l}\text { A majdani iskolai-nevelési } \\
\text { munkában módszertanilag is } \\
\text { hasznosítható, gazdagabb } \\
\text { ismeretanyag tanítása }\end{array}$ & $\begin{array}{l}\text { Elméleti és módszertani órák, az } \\
\text { információs „írástudás” } \\
\text { készségeinek fejlesztéséhez szük- } \\
\text { séges eszközök }\end{array}$ \\
\hline $\begin{array}{l}\text { Informatikusképzés(könyvtár- } \\
\text { és dokumentációtudomány) }\end{array}$ & $\begin{array}{l}\text { Az informatika társadalmi, } \\
\text { humán oldalának bemutatása }\end{array}$ & $\begin{array}{l}\text { Szabadon vagy kötelezôen } \\
\text { választható tárgy }\end{array}$ \\
\hline Felnőttképzés & $\begin{array}{l}\text { Általános ismeretterjesztés, } \\
\text { szemléletformálás, } \\
\text { igényfelkeltés, „hidak” más kur- } \\
\text { rens tudásvilágokhoz }\end{array}$ & Szabadegyetem, nyári egyetem ${ }^{7}$ \\
\hline
\end{tabular}

\section{Hogyan tanítsuk aะ információs társadalommal foglalkozó tárgyat az egyetemen?}

„Rövid válasz: próbáld ki az összes módszert, amit a világban eddig kidolgoztak!" (Duff 2001b)

Korábban láttuk, hogy az információs társadalommal foglalkozó tárgy - a mögötte álló tudományos ismeretek szélsőségesen multidiszciplináris voltára visszavezethetốen ${ }^{8}$ - rendkívül összetett. Tartalmi határai amóbaként alakulnak, a választott diskurzusok megjelenítése maga a tárgy határainak kijelölése. Hornby (Hornby

\footnotetext{
${ }^{8}$ Ehhez társul az, amit Duff (2001a) anyatudományi meghatározottságnak nevez: bármely diszciplína képviselője, ha találkozik az információs társadalom témakörével, azonnal tud közös metszeteket képezni azzal, akár közlekedésmérnök, akár menedzser, akár idegen nyelv szakos hallgatókról van szó.

${ }^{6}$ Hazai képzésük előkészítés alatt all a Budapesti Gazdasági Főiskolán (BGF).

${ }^{7}$ Ld. például a Tartui Nyílt Egyetem kurzusait az információs társadalomról,www.ut.ee/av/summer/ItIS.php, ill. hazánkban a Stratégiakutató Intézet nyári mesteriskoláját.
} 
2001) szerint a témaválasztásoknál és a tárgy dramaturgiai ívének kijelölésekor egyenesen a bernsteini „framing”, a tárgyalási univerzum kereteinek kijelölése ${ }^{9}$ tûnik az egyik lehetséges útnak. Ez azonban Duff (Duff 2001a) szerint nem változtat azon, hogy a diákok bizonyosságot és szilárd tanokat (certainty and dogma) követelnek, amit viszont az oktatók adni tudnak, az - a jelzett okok következtében - mindössze az árnyalatok és többértelmúségek (nuance and ambiguity) világa. Emiatt felértékelődik az oktató saját viszonyulása az információs társadalom jelenségeihez: az, hogy a tanár mennyire szkeptikus vagy milyen vízióval rendelkezik, döntően meghatározza a lehetséges kurzusok irányát és tartalmát. ${ }^{10}$

Abban viszont közmegegyezés látszik kialakulni, hogy a tudásvilág természete megköveteli, hogy a magas színvonalú „akadémiai” nézőpontokat egészségesen kell összevegyíteni az esettanulmányok praxis-szintjével.

Black (Black 2001) az információs társadalomra vonatkozó ismereteket oktató kurzusoktól azt várja el, hogy elvégzésükkel a diákok képessé váljanak

- azonosítani és értékelni (identify and assess) az információs társadalom alternatív megközelítéseit;

- felmérni az információ-jelenség szerepét és jelentőségét a modern társadalmi átalakulásokban;

- felismerni a történeti kontextust;

- megalapozott véleményt kialakítani az információs szakemberek szerepéről, annak etikai konzekvenciáival együtt; és

- jobban megérteni a társadalmat átjáró információs szolgáltatások mélyszerkezetét.

A tudományterület sajátosságai és a módszertani megfontolások „elegyítésével” Alistair Black megalkotta a tantárgy ,ideáltípusának” alapmoduljait:

\footnotetext{
${ }^{9}$ Nála: „a létezố világok legjobbika” panglossi kritikátlansága helyett.

${ }^{10} \mathrm{Ez}$ az erôs függés az oktató személyétốl lehet jó is, és lehet rossz is a tárgy szempontjából. Az információs társadalommal foglalkozó szakirodalmat vastag szemétréteg fedi, amelyet a média szenzációéhes szereplôi és a tudomány félperifériájának gondolatrest dilettánsai naponta tovább vastagítanak. Iszonyú mennyiségû́ félig megrágott közhely, széles körben terjedố ostobaság várja, hogy fejekbe, szívekbe és tantervekbe kússzon. Hódít a fogalmi zsonglőrködés, a „fekete oldal” túlhangsúlyozása, a „Nagy Testvér” emlegetése, miközben az információs társadalmat curriculum-zászlóra tûző trendlovagok gyakorta és szívesen mondogatják, hogy „tulajdonképpen nem is tudjuk, mi is az információs társadalom”. Ennek a tudománynak is megvannak a maga Danikenjei: David Schenk például, akinek "Adatszmog" címû fércmûve kurzusok tucatjaiban jelenik meg szakirodalomként, s aki legújabban a National Geographic szerkesztőinek gondatlansága folytán a fél világnak a „,felügyelet alatt álló társadalom” (surveillance society) mumusát mutogatja: a riogatáshoz van elég ereje, a jelenségek következetes rendszerbe szervezéséhez és elemzéséhez nincs.
} 
Az információs társadalommal foglalkozó tárgy ideáltípusa Black (2001) szerint

Az információs társadalom fogalma (historiográfia, teoretikusok, vita)

Tudás, információ és társadalom (bevezetés az információ- és tudásszociológiába, a tudás és az információ közti különbség, kommunikációelmélet, szemiotika, technológiai determinizmus)

Gazdaság

Kormányzat és politika

Kultúra és társadalom

Alternatív deszkriptorok (a „rivális” elméletek szemléje a kockázattársadalomtól a tudástársadalomig)

Történeti információs társadalmak (szóbeliség, írásbeliség, az információtechnológia kultúrtörténete, az információfeldolgozás nagy forradalmai)

Black „ideáltípusa” körül nem szükséges sokat időznünk: erényei és gyengéi egyaránt számosak, alapvetô hibája az, hogy nem differenciál. Megmutatjuk viszont a Varga Csaba és munkatársai által mintatárgyként kifejlesztett - Black ideáltípusához hasonlóan „homogén” - két féléves kurzus moduljait, a közös pontok mellett a sajátunktól eltérố szemlélet és szóhasználat illusztrálása végett. ${ }^{11}$

\begin{tabular}{|l|}
\hline Az információs társadalom elmélete. (Varga, 2002) \\
A globlokál világ \\
\hline Az információs társadalom fogalma \\
\hline ICT - technológia és informatika \\
\hline A tudásalapú gazdaság \\
\hline Az információs társadalom mint Új Társadalom \\
\hline Az információs polgár és/vagy tudáspolgár \\
\hline Az információs kor tartalma (e-content) \\
\hline A magyar információs társadalom \\
\hline A magyar információs társadalom fejlesztése \\
\hline A tudástársadalom mint az információs társadalom jövốképe \\
\hline
\end{tabular}

Ahhoz azonban - fogalmazza meg Earl (Earl 2001) -, hogy lefutott kurzusokról, módszertanokról és gyakorlatokról lehessen megalapozottan vitatkozni, még néhány évig várni kell: amíg megfelelő mennyiségú gyúanyag nem halmozódik fel a reflexióhoz, marad a kontempláció.

\section{Információs társadalom oktatás Magyarorsะágon}

Talán meglepően hangzik, de nemzetközi összehasonlításban Magyarország az információs társadalommal foglalkozó felsôfokú kurzusok tekintetében az élboly egyik legfürgébb és leginkább sokszínű szereplője. A Budapesti Műszaki Egyetemen

\footnotetext{
${ }^{11}$ A tantárgyi modulok mellett a „Mit kell oktatni és hogyan?” kérdésre adott válaszok igazítanak el avval kapcsolatban, hogy a képzés gazdái mely aspektusokat tartják fontosnak kiemelni. 1. Új, globális tudás, új gondolkodás, az új tudomány átfogó tételeinek ismertetése 2. Globalizáció- és lokalizáció-elmélet 3. Cselekvéselmélet, innovációelmélet, információs kori társadalomfejlesztés 4. Komplex emberelmélet, jövőorientált mentalitás, tudásalapú munkaerôpiac.
} 
már évekkel azelőtt, hogy a kilencvenes évek közepén bekövetkezett a társadalmi informatika „emancipációja”, alaptárgyat és kurzusokat tartottunk; 1992-től „információtörténelmi” képzés folyt az ELTE-n; s 1993-ban önálló tárgy oktatása indult meg ismét csak a Műegyetemen „Információs társadalom” címmel, amit 1995-ben már önálló egyetemi jegyzet támogatott. Miközben a világ szép lassan eljutott saját szintetikus kurzusaihoz az információs társadalom témakörében, a BME-n már az egyes modulok önálló tárggyá való továbbfejlesztésénél tartottunk. A bevezető, ismeretterjesztô jellegú „Információs társadalom” címû tárgy mellett kurzussá szerveztük a politikai programmá érő „Információstratégiák” ismereteit, Black általános információelméleti modulját pedig - féléves tárgyként - „Az információ társadalomelmélete" címen vezettük be. Elindult az információrendszerek kultúrtörténetével foglalkozó szeminárium, és az Internet-jelenséget is egyedileg kifejlesztett tantárgyak követik.

A kilencvenes évek végén az információs társadalom tematikája megjelent a szociológusképzésben, ${ }^{12}$ majd sok kicsi, dinamikus fôiskola kínálatában. ${ }^{13}$ Megérett az idő, hogy még merészebb vállalkozásba fogjunk. 2001 őszén megkezdtük egy országos kiterjedésű oktató és kutató hálózat létrehozását, amely az „Információs Társadalom Oktató és Kutató Csoportok" (ITOK) nevet kapta. ${ }^{14}$

Az ITOK munkatársai oktatóként az adott intézmény alkalmazottai, miközben kutatóként részesei a hazai információs társadalmat vizsgáló különbözố kutatási programoknak. A vidéki egyetemek és főiskolák ITOK-jai regionális ismeretterjesztő és „think tank”-szerepet játszanak. Az „Információs társadalom” címú tárgy oktatását hálózatba szerveződve végzik (tantárgykoncepció, vázlat, tankönyv, szakmai kiadványok, szemléltető anyagok, továbbképzés, tapasztalatcsere). Az adott intézmény profiljába vágó témák múvelésével oktatóként és kutatóként is specializálódnak. A befogadó intézmények kísérleti jelleggel, 2 évre hozták létre a csoportokat, ez alatt az idő alatt kutatási tevékenységük segítségével önfenntartóvá kell válniuk.

Az „Információs társadalom oktató és kutató csoport” olyan 1-3 főből álló sejt, amely szervezetileg az adott intézmény valamelyik (téma-barát) tanszékéhez, intézetéhez vagy más szervezeti egységéhezsoportjához tartozik, vezetôjét relatív szervezeti és pénzügyi önállósággal nevezik ki. A csoportok átlagosan két tárgy oktatásával vannak jelen az intézményben:

${ }^{12}$ 2003-ra a Magyar Szociológiai Társaság évi vándorgyưlésének kiemelt témájává vált az információs társadalom. Az ELTE-n Heller Mária és Dessewffy Tibor neve fémjelzi ezeket a kurzusokat, illetve a korai adaptációt.

${ }^{13}$ Volt olyan év, amikor a fiatal szociológus-politológus, Pintér Róbert egymaga négy különböző felsőoktatási intézményben vezetett kurzusokat az információs társadalom témakörében.

${ }^{14} \mathrm{Az}$ országos kiterjesztésre és a felsổoktatás maradéktalan „lefedésére” való igény természetesen következik a terület stratégiai kezelésébốl. „A fôiskolákon és egyetemeken ... mindenhol meg kellene hirdetni az "Információs társadalom" tantárgyat, amely természetesen tartalmazza az összes fontos új ismeretet, kezdve az információelmélettôl az e-demokrácia gyakorlatának oktatásáig” (Varga 2002). 
1. „Információs Társadalom” címmel egy olyan alaptárgyat tanítanak, amely annak köszönhetően, hogy tematikája, tankönyve, szemléltető anyaga és megújuló szakirodalma (elsősorban a naprakészséget biztosító Infinit Hirlevél és az Infonia könyoprogram révén) biztosított - országosan többé-kevésbé egységesnek tekinthetô. A tanárok évente kétszer múhelykonferencián találkoznak, és ezt a „közös” tárgyat saját tapasztalataikkal, innovációikkal folyamatosan fejlesztik.

2. Az „információ és társadalom” tematikáján belül valamely általuk művelt részterületen speciális kurzusokat tartanak

A csoportok munkatársai helyi egyetemi vagy főiskolai kollégáikkal és diákjaikkal saját kutatási programokat folytatnak, amelyek részben az információs társadalom regionális kutatásának tekinthetôk, tehát adott lokalitásokra érvényesen alkaImaznak közös tudásokat, illetve orientálódnak a praxis felé. Mindezek növelik az intézmény vonzerejét és lépéstartásról, frissességről üzennek a szakmai köröknek és a leendő diákoknak is.

\section{3. táblázat}

$\mathrm{Az}$ „elsố körben” létrejött és a megalapítás elôtt álló ITOK-ok

\begin{tabular}{l|l|l} 
Néo & Város & Megalakulás éve \\
\hline Széchenyi István Egyetem & Gyôr & 2003 \\
\hline Miskolci Egyetem & Miskolc & 2003 \\
\hline BME & Budapest & 1999 \\
\hline ELTE Ithaka & Budapest & 2002 \\
\hline Eszterházy Károly Fóiskola & Eger & 2003 \\
\hline Általános Vállalkozási Fốiskola & Budapest & 2002 \\
\hline Iparmúvészeti Egyetem & Budapest & 2003 \\
\hline Budapesti Gazdasági Fôiskola (BGF) & Budapest & 2003 \\
\hline Nyíregyházi Tanítóképzó Fôiskola & Nyíregyháza & 2003 \\
\hline Janus Pannonius Tùdományegyetem & Pécs & 2003 \\
\hline Közgazdaságtudományi Egyetem (BKE) & Budapest & 2003 \\
\hline Nyugat-Magyarországi Egyetem & Sopron & 2003 \\
\hline
\end{tabular}

A program két irányban folytatódik. Terveink szerint 2004 végére már 25 felsőoktatási intémény tartozik bele az ITOK-körbe, és az Európai Unió szintjén is páratlan erejư és hatékonyságú hálózat jön létre. ${ }^{15}$ Másfelől a hálózatképzésben rejlő erôt és a „franchise” jellegủ elemek (a hasonló szemlélet, a részben közös tananyag és kézikönyvtár), továbbá a mobilitás és az e-learning lehetôségeit kihasználva az ITOK-hálózatot ki kívánjuk terjeszteni a környező országokban élố magyar lakosság szellemi centrumaira is:

\footnotetext{
${ }^{15}$ A programot a Budapesti Mûszaki és Gazdaságtudományi Egyetem gondozza. A csoportok mûködését az Informatikai és Hírközlési Minisztérium kétéves támogatása teszi elindíthatóvá.
} 
4. táblázat

\begin{tabular}{l|l|} 
Város & Ország \\
\hline $\begin{array}{l}\text { Kolozsvár } \\
\text { Csíkszereda } \\
\text { Marosvásárhely }\end{array}$ & Románia \\
\hline Révkomárom & Szlovákia \\
\hline Szabadka & Szerbia \\
\hline Eszék & Horvátország \\
\hline Lendva & Szlovénia \\
\hline Munkács & Ukrajna \\
\hline
\end{tabular}

5. Hogyan tanitsuk az információs társadalommal kapcsolatos ismereteket a középiskolában?

Hiába vonult be a Sulinet és az Internet a középiskolába a tanulás és a szórakozás hétköznapjainak mindinkább észrevehetetlen szereplőjeként, a globális közösség és az azt összekapcsoló információtechnikai infrastruktúra kérdéskörének szellemi síkon való megközelítése kívül maradt az iskolafalakon. Miközben az információs társadalom kérdéskörét rendre ott találjuk a társadalomelmélet (és a politikai stratégia-alakítás) legnagyobb kihívásai között, ez mindeddig nem minôsült közvetítésre érdemes tudásanyagnak a középiskolában. A számítógéphasználat fortélyainak ismerete, a digitális tanulási környezet már régóta téma. Annak közvetítése, hogy mindez miképp ágyazódik be a nagyléptékû társadalmi-gazdasági-kulturális változásokba, milyen jövóképet rajzol ki, milyen veszélyeket idéz fel és milyen kétségeket támaszt, nem talált magának helyet.

Amikor az osztályfőnöki órák időkínálatát kihasználva tíz órás blokkot alakítottunk ki, ${ }^{16}$ az a cél vezetett minket, hogy elóbb-utóbb minden középiskoláshoz az oktatási programok részeként juthasson el az információs társadalom kérdéskörének néhány különösen fontos összefüggése, és azok intellektuális megközelítése. Az információs társadalom témakörének roppant gazdagságából oly módon válogattuk ki és állítottuk össze az alábbi 10 témát, hogy azok egyszerre feleljenek meg két kritériumnak:

- tartozzanak az információs társadalom jelenségeit vizsgáló tudományok elfogadott diskurzusaihoz;

- olyan kérdéseket öleljenek fel, amelyek a mai középiskolás korosztály számára értelmezhetôk, fontosak, s a tanulók mindennapjaiban is gazdag jelentéssel „leképezhetők”.

\footnotetext{
${ }^{16}$ Hutai László (Karinthy Gimnázium, Budapest) és Z. Karvalics László (BME).
} 
5. táblázat

A tíz osztályfơnöki óra tematikája

\begin{tabular}{l|l} 
Sorszám & Témakör \\
\hline 1. & A harmadik hullám: az információ- és tudás-alapú jelen és jövő \\
\hline 2. & Balvélekedések és tévhitek - a gondolkodás csapdái \\
\hline 3. & A globális információs társadalom - méretek, rendszerek, evolúció \\
\hline 4. & Gazdaság és pénz az e-korszakban \\
\hline 5. & Az információs társadalom és a politika világa \\
\hline 6. & Egyén és közösség, család és munkahely - változások és választások \\
\hline 7. & Beszéljünk az Internetrôl és a hálózati polgárokról, a „netizenekrôl”! \\
\hline 8. & Intelligens város, intelligens közlekedés, intelligens otthon \\
\hline 9. & Kockázatok az információs társadalomban. Jövôképek: Orwell vagy Athén? \\
\hline 10. & A legfrissebb fejlemények: hír- és trendelemzések \\
\hline
\end{tabular}

Tanári kézikönyvet állítottunk össze, amely tartalmazza a 10 óra javasolt felépítését, témaköreit, az egyes témákhoz rendelt „ismeretcsomagokkal” (állítások, adatsorok, illusztrációk, táblázatok). Minden egyes óra témájához hozzátartozik egykét ajánlott szakirodalmi forrás, a még mélyebb érdeklődés kielégítéséhez pedig további olvasnivalókat és az Interneten elérhetô „lelôhelyeket” is kínálunk.

Minden óra anyagához didaktikai javaslatokat teszünk, és olyan forrásokra is felhívjuk a figyelmet, amelyek a tíz részből álló kurzus befejezése után is folyamatosan naprakészen tarthatják mind a tanár, mind a diákok ezirányú tudását. Ehhez a programban résztvevố tanárok számára egy weboldalt építünk, ahol tájékozódhatnak, eszmét cserélhetnek, és újabb szakirodalmi segítséget, illetve háttéranyagokat kaphatnak. A weboldal a tapasztalat-csere mellett a programok bővítésének és standardizálásának is alkalmas eszközévé válhat.

A tanári kézikönyv, az ajánlott olvasmányok, a weboldal és az onnan elérhető további források nagyszerû lehetôséget adnak ahhoz, hogy bárki, bármikor elindíthassa a programot. Szeretnénk füzet formájában is megjelentetni mindezt, hogy még inkább segíteni tudjuk a csatlakozni kívánók munkáját. A legizgalmasabb lépés azonban az volna, ha a programban érintett tanárok párbeszéde, eszmecseréje is kialakulhatna, hiszen így már az elsô oktatási év tapasztalatai alapján elkészülhetne egy közös „bölcsességgel” továbbfejlesztett, országos elterjesztésre ajánlható program. Mindez azt jelenti, hogy a kipróbálás ütemezés szerinti első fél éve után egy másik fél év szükséges ahhoz, hogy szervezetten bele lehessen vágni a program országos szintű megvalósításába. Annak a megjósolására azonban, hogy a tanárképzésben mikor jelenhet meg általánosan elfogadott tárgyként az információs társadalom tematikája, nem merünk vállalkozni. Ne feledjük: még mindig csak egy folyamat elején járunk. 


\section{IRODALOM}

Black, Alistair (2001): The scope of the syllabus of information society studies. Education for Information 19. (IOS Press) pp. 245-252.

Danyi Pál - Gelléri Péter - Z.Karvalics László (1993): Bevezetés a társadalmi informatikába. In: Informatika a felsôoktatásban I. (Debrecen, 1993) 292-298.

Duff, Alistair S. (2000): Information Society Studies. Routledge, London, 2000

Duff, Alistair S. (2001a): Teaching the Information Society: Guest Editorial to a One-Day

Symposium, hosted by the School of Communication Arts. Napier University, Edinburgh, 18th May 2001. Education for Information 19 (2001) pp. 227-229. (IOS Press)

Duff, Alistair S. (2001b): On the present state of information society studies. Education for Information 19 (2001) pp. 231-244. (IOS Press)

Dutton, William H. (1996): Information and Communication Technologies: visions and realities. Oxford University Press, Oxford, 1996

Earl, Shirley (2001): What to teach or how to teach it? A reflection on ,Teaching the Information Society". Education for Information 19 (2001) pp. 263-265. (IOS Press)

Hornby, Susan (2001): Teaching the information society: Pragmatism or pangloss? Education for Information 19 (2001) pp. 253-257. (IOS Press)

Varga Csaba (2002): Az információs társadalom oktatása. eVilág, 2002/10. pp.11-13

Warner, Julian (2001): The summary of the day's discussion. Education for Information 19 (2001) pp. 259-261. (IOS Press)

Webster, Frank (1995): Theories of the Information Society. Routledge, London, 1995

Z. Karvalics, Lászlo (1998): Information Society and Social Informatics: extended topology of the research fields. In: Proceedings of the Conference on Research for the Information Society, Warsaw, 15-17. October, 1998

Z. Karvalics László (2001): Bevezető a információs társadalom tudománytörténetéhe:. Információs Társadalom, 2001/1 (december) 34-48. 